\title{
Women Education and Political Participation in the South West Region of Cameroon: An Empirical Analysis
}

\author{
Kinge Ruth Fanny ${ }^{1}$ \& Adepoju Oluwasanumi A. ${ }^{2}$ \\ ${ }^{1}$ Department of Political Science, Gombe State University, Nigeria \\ ${ }^{2}$ Department of Education, Gombe State University, Nigeria \\ Correspondence: Kinge Ruth Fanny, Department of Political Science, Gombe State University, Nigeria. E-mail: \\ rkfanny@yahoo.com
}

\author{
Received: May 4, 2014 Accepted: May 19, 2014 Online Published: October 29, 2014 \\ doi:10.5539/par.v3n2p144 \\ URL: http://dx.doi.org/10.5539/par.v3n2p144
}

\begin{abstract}
The paper empirically examined the relationship between education level and political participation of women of the South West region of Cameroon. The indices of political participation include the following: membership of political party, voting in elections, occupation of political post, means of occupation of political post and level of occupation of political post. Multistage cluster sampling technique was used to select the sample population of the study. A total of 222 women constituted the sampled population for the study. Data for the study was collected using structured questionnaire. Data analysis was done using descriptive and inferential statistical tools. The results revealed that women of the South West region of Cameroon are fairly well exposed to formal education as only $4.1 \%$ of the sampled population had no formal education. The study revealed that the higher the level of women's formal education, the more their tendency to participate in politics in areas of voting in elections and occupation of political post either through elections or appointments at all levels of government.
\end{abstract}

Keywords: women, education, political participation

\section{Introduction}

In recent times, nations of the world have witnessed increased discussions and debates on gender issues with emphasis on women liberation, emancipation, empowerment, protection of women rights, and women participation in politics among others. In order to ensure women development in modern democracies, governments, world organizations and various stakeholders at different levels have made declarations that are supposed to be binding on member States among which include the United Nations Declaration on Human Rights, which prohibit all forms of discriminations based on sex and ensure the right to life, liberty and security (UNDP, 2005).

The 1979 UN Convention on the Discrimination against Women (CEDAW) addressed issues pertaining to the rights of women to education, inheritance, credit and opportunities on equal bases with men. It also reaffirmed the equality of human rights for women and men in societies and in the family. In the same vein, it obliged States to take actions against the social causes of women's inequality; called for the elimination of laws, stereotype practices and prejudices that impair the wellbeing of women (UNDP, 2005). The World Conference on Human Rights in 1993 at Vienna affirmed that "women's rights are human rights" (Delahanty, 2005: 5-10). The Beijing platform of Action in 1999 re-emphasized the protection of women from domestic violence and sexual harassments.

In the wake of all these developments, women in Cameroon are still restricted in almost all important areas of human capabilities. In the South West region of the country, awoman's status is still a reflection of the stereotype cultural views of a woman's role in the society being that of child-raising and home-making. Women are afforded limited opportunities to explore wider aspirations and attaining to her maximum potentials (especially in the socioeconomic and political spheres) outside these cultural stereotype boundaries (UN Women' Watch, 2014). This invariably has resulted in the girl-child being provided little or no opportunities for further education. Thus, women tend to have limited access to formal education as she is often forced into early marriage. (Abua \& Fonchong, 2004).

With specific reference to formal education, political participation has been reported to have strong links with education. As an example, Burns, Schlozman and Verba (1997: 373-389) have posited on the basis of decades of 
researches into the factors influencing individuals' engagement with politics in the USA, that education is an 'especially powerful predictor of political participation'. They further identified a range of direct and indirect effects that formal education has upon political participation.

Directly impacting on the study is their identification of a range of direct and indirect effects that formal education has upon political participation. Some of these effects they noted include: - the acquisition of knowledge and communication skills useful for public debate, direct trainings in political analysis through courses with current events contents. While in its indirect form, the effect of formal education creates avenues for benefits of voluntary engagement in schools, clubs, sports, and newspapers; these arenas, they concluded provide young people with early apprenticeship politics where they can exercise leadership, develop civic skills of cooperation and negotiation and acquire bureaucratic and organizational skills useful for political activities.

The implication of these results is that education clearly enhances the chances of individuals' participation in politics as it provides necessary skills and knowledge needed for it. Rosenstone and Hansen (1993: 136) argue that education "imparts the knowledge and skills most essential to a citizen's task. As a result of their schooling, the well- educated have the skills people need to understand the abstract subject of politics, to follow the political campaign, and to research and evaluate the issues and candidates".

Although women account for $51 \%$ of Cameroon's population yet they occupy $13 \%$ of the political and decision making system of the country. For example, only $6.7 \%$ of Mayors in Cameroon are females, $13 \%$ of the members of parliament are females; and none of the regional governors is a female ( Ministry of women affairs, 2010).

This scenario should not be unexpected with the expectation that to marry young constitutes additional barrier to women's pursuits of higher education. Many young girls stop going to school well before their male counterparts, the resultant effects being their engagement in low-paying jobs such as petit trading, a situation which impact tremendously on their public status as well as difficulties in being able to compete against male candidates in elections. Without access to the same level of education, women will continue to have to fight even harder for the same opportunities. This situation is one of the main contributing factors hindering women from participation in politics

(http://www.asafeworldforwomen.org/womens-rights/wr-africa/w-cameroun/624-women-in-cameroon. $\mathrm{html})$. This situation is aptly summarized in Table 1 . The table revealed that, only $15.8 \%$ of Municipal Council Councilors in South West Region of Cameroon are females. This obviously is a pathetic situation far short of the recommended benchmark of 30\% at the 1999 Beijing Conference. 
Table 1. South west region of Cameroon: Data on municipal councils' councilors between 2007 and 2013

\begin{tabular}{|c|c|c|c|c|}
\hline Division & Council & No. of councilors & No. of Women & $\%$ of female Councillors \\
\hline \multirow{9}{*}{ Fako } & Buea & 41 & 15 & 36.6 \\
\hline & Idenau & 25 & 3 & 12.0 \\
\hline & Limbe I & 25 & 3 & 12.0 \\
\hline & Limbe II & 25 & 3 & 12.0 \\
\hline & Limbe III & 25 & 3 & 12.0 \\
\hline & Muyuka & 41 & 7 & 17.1 \\
\hline & Tiko & 41 & 9 & 22.0 \\
\hline & *Limbe City & 19 & 4 & 21.1 \\
\hline & Bangem & 25 & 3 & 12.0 \\
\hline \multirow[t]{3}{*}{ KupeMwanenguba } & Nguti & 25 & 3 & 12.0 \\
\hline & Tombel & 25 & 3 & 12.0 \\
\hline & Alou & 25 & 3 & 12.0 \\
\hline \multirow[t]{3}{*}{ Lebialem } & Menji & 25 & 3 & 12.0 \\
\hline & Wabane & 25 & 3 & 12.0 \\
\hline & Akwaya & 31 & 1 & 3.2 \\
\hline \multirow{3}{*}{ Manyu } & Eyumojock & 25 & 3 & 12.0 \\
\hline & Mamfe & 25 & 5 & 20.0 \\
\hline & Tinto & 25 & 3 & 12.0 \\
\hline \multirow{6}{*}{ Meme } & Konye & 25 & 3 & 12.0 \\
\hline & Kumba I & 25 & 5 & 20.0 \\
\hline & Kumba II & 25 & 3 & 12.0 \\
\hline & Kumba III & 25 & 3 & 12.0 \\
\hline & Mbonge & 35 & 6 & 17.1 \\
\hline & *Kumba City & 19 & 4 & 21.1 \\
\hline \multirow{9}{*}{ Ndian } & Bamusso & 25 & 5 & 20.0 \\
\hline & DikomeBalue & 25 & 3 & 12.0 \\
\hline & EkondoTiti & 25 & 4 & 16.0 \\
\hline & Idabato & 25 & 5 & 20.0 \\
\hline & Isangele & 25 & 8 & 32.0 \\
\hline & KumboAbedimo & 25 & 6 & 24.0 \\
\hline & KumboItindi & 25 & 11 & 44.0 \\
\hline & Mundemba & 25 & 6 & 24.0 \\
\hline & Toko & 25 & 5 & 20.0 \\
\hline Total & & 877 & 139 & 15.8 \\
\hline
\end{tabular}

*City Council derive their councilors from the Sub Divisional Councils

SOURCE: MUDEC GROUP, 2013, BUEA CAMEROON.

This low participation of women in politics in the region is a source for concern as revealed in the Table. This low engagement of women in politics in the south west region of Cameroon is not unconnected with the fact that the level of education of women in the region is low.

Although there is no universally accepted definition of political participation, however, broadly speaking, political participation may be regarded as participating in the political process, such as voting and occupying a political post. 
Although voting in elections is a more direct indicator of political participation, getting information on the occupation of political post is a better option of the measurement of political participation. Huntington \& Nelson (1976: 3) explained "by political participation we mean activity by private citizens designed to influence government decision-making." Verba, Schlozman, and Brady, (1995: 38) informed that political participation refer "simply to activity that has the intent or effect of influencing government action - either directly by affecting the making or implementation of public policy or indirectly by influencing the selection of people who make those policies".

The Oxford University Press Online Resource Centre (2014) further informs that there could be both legal and illegal dimensions to political participations, however as regards legal and voluntary political participation; it points out that the general public in a democratic setting may participate in politics in three different ways:

1) People can get involved in a public arena to advertise and communicate demands to anyone willing to listen. Example: joining a demonstration.

2) People may target policy-makers in legislatures or the executive branch as addresses of their communications. Example: signing a petition.

3) People may get involved in the selection process of those who aspire to legislative or executive office. Examples: voting for a party or running for office.

This study thus situates political participation within the context of the following indices: membership of political party; voting in elections; occupation of political post; means of occupation of political post and level of occupation of political post.

To this end, this study was designed to empirically document the educational status of women in the South West Region of Cameroon and to determine the relationship between women education status and their levels of political participation.

The following research questions guided the study:

1) What is the profile of the educational status of women in the South West region of Cameroon?

2) Is there a significant relationship between women educational attainment and their political participation in the region?

\section{Methodology}

\subsection{Population and Sampling}

The population of the study comprises women in the South West Region of Cameroon. In the South West region of Cameroon, there are 6 administrative units. Multistage cluster sampling technique was used to select the sample population for the study. From the 6 administrative units, 3 sub administrative units were randomly selected, from each of the selected 3 sub administrative units, 2 sub units were randomly selected, in all, study sample comprised 6 sub units. From each of the selected 6 sub units, 1 village was randomly selected and from each of the selected 6 villages, 1 main street was selected using simple random sampling. Further 50 households that had women of at least twenty years and above were selected from each of the 6 selected main streets. Through this procedure, a total of 300 women were selected for the study.

\subsection{Data Collection Instrument}

In order to investigate the impact of education on women's political participation in the South West region, questionnaire which consisted of two parts was developed by the researchers. . Section A solicited for information on respondents' educational level. Section B requested for information as regards respondents' extents of involvements in the following pre-specified indices of political participation: membership in political party; voting in elections; occupation of political post; means and levels of occupation of political post. A total of 222 (74\% of administered questionnaires) were returned.

\subsection{Data Analysis}

To analyze the data collected for the study, a combination of inferential and descriptive statistical techniques were used. These were presented in the form of frequency distribution table and simple percentages.

\section{Results, Discussion and Conclusion}

\subsection{South West Region of Cameroon Female Educational Level Profile:}

As regards the educational background of the respondents, the results are summarized in Table 2 and Figure 1. 
Table 2. South west region of Cameroon female educational level

\begin{tabular}{lcc}
\hline \multicolumn{1}{c}{ Educational Level } & Frequency & Percentage \\
\hline No formal Education & 9 & 4.1 \\
First School Leaving Certificate & 42 & 18.9 \\
G.C.E. O Level & 69 & 31.1 \\
G.C.E. A Level & 48 & 21.6 \\
University Degree and above & 63 & 28.4 \\
Total & 222 & 100.0 \\
\hline
\end{tabular}

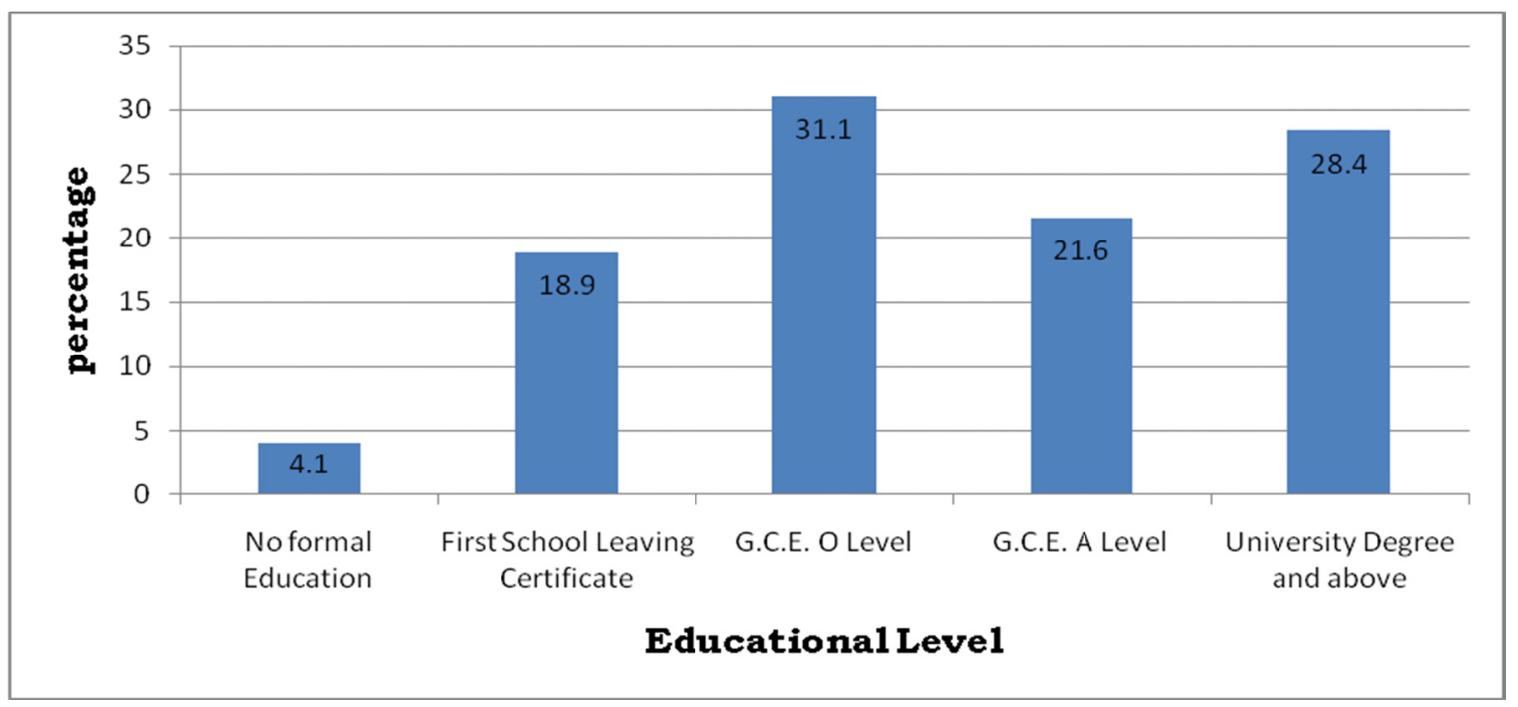

Figure 1. Chart indicating the distributions of women of the south west region of Cameroon by educational level

The results indicate that only about $4.1 \%$ of the respondents have no formal education. This result tends to be consistent with the estimated $90 \%$ literacy rate for the region (UNDP, 2014). The results further indicate that at least $50 \%$ of women in South West Cameroon had a secondary school education. The educational level that has the highest proportions of respondents is the GCE ordinary level which is the results possessed by $31.1 \%$ of the respondents and as much as $28.4 \%$ had at least a university degree. These thus indicate that the women of the South West region of Cameroon are fairly well exposed to formal education.

\subsection{South West Region of Cameroon Women's Political Participation Based on Their Educational Level}

With regards to the relationship between participation of women of the south west region of Cameroon and their educational level, the results are summarized in Table 3 
Table 3. South west region of Cameroon women's political participation based on the educational level

\begin{tabular}{|c|c|c|c|c|c|c|c|c|c|c|}
\hline \multirow[b]{2}{*}{ SN } & \multirow{2}{*}{$\begin{array}{l}\text { Index of } \\
\text { political } \\
\text { participation }\end{array}$} & \multirow[b]{2}{*}{ Level } & \multicolumn{6}{|c|}{ Responses } & \multirow{2}{*}{$\underset{\substack{\text { Pvalue } \\
\text { Pvalu }}}{\mathrm{X}^{2}}$} & \multirow[b]{2}{*}{ Remark } \\
\hline & & & NIL & FSLC & $\mathrm{OL}$ & $\mathrm{AL}$ & DEGREE & TOTAL & & \\
\hline \multirow[b]{2}{*}{1} & Registered & A member & 3 & 15 & 18 & 18 & 24 & $78(35.1)$ & \multirow[b]{2}{*}{0.32} & \multirow[b]{2}{*}{ NS } \\
\hline & $\begin{array}{l}\text { Membership of } \\
\text { Political Party }\end{array}$ & Not a member & 6 & 27 & 51 & 30 & 30 & $144(64.9)$ & & \\
\hline \multirow{2}{*}{2} & Voting in Last & Voted & 3 & 12 & 24 & 18 & 36 & $93(41.9)$ & \multirow{2}{*}{0.04} & \multirow{2}{*}{ SIG } \\
\hline & Elections & Did not Vote & 6 & 21 & 45 & 30 & 27 & $129(58.1)$ & & \\
\hline \multirow{2}{*}{3} & Occupation of & $\begin{array}{ll}\text { Political Post } \\
\text { Occupied }\end{array}$ & 0 & 5 & 7 & 12 & 15 & $39(17.6)$ & \multirow{2}{*}{0.23} & \multirow{2}{*}{ NS } \\
\hline & Political Post & $\begin{array}{l}\text { Political Post } \\
\text { not Occupied }\end{array}$ & 9 & 21 & 57 & 42 & 54 & $183(82.4)$ & & \\
\hline \multirow[b]{2}{*}{4} & Means of & $\begin{array}{l}\text { Through } \\
\text { Elections }\end{array}$ & 0 & 3 & 3 & 6 & 6 & $18(8.1)$ & \multirow{6}{*}{\multicolumn{2}{|c|}{$\begin{array}{l}\text { Computation } \\
\text { not possible } \\
\text { At least an } \\
\text { expected value } \\
=0\end{array}$}} \\
\hline & $\begin{array}{l}\text { Occupation of } \\
\text { Political post }\end{array}$ & $\begin{array}{l}\text { Through } \\
\text { Appointments }\end{array}$ & 0 & 2 & 4 & 6 & 9 & $21(9.5)$ & & \\
\hline \multirow{4}{*}{5} & \multirow{4}{*}{$\begin{array}{l}\text { Level } \\
\text { Occupation } \\
\text { Political Post }\end{array}$} & \multirow{3}{*}{$\begin{array}{l}\text { National } \\
\text { Regional }\end{array}$} & 0 & 0 & 0 & 1 & 3 & $4(1.8)$ & & \\
\hline & & & 0 & 0 & 1 & 1 & 2 & $4(1.8)$ & & \\
\hline & & & 0 & 0 & 0 & 3 & 4 & $7(3.2)$ & & \\
\hline & & Sub-Divisional & 0 & 3 & 6 & 6 & 9 & $24(10.8)$ & & \\
\hline
\end{tabular}

Source: Fieldwork survey Dec 2011-January 2012 (Percentages of respondents in Parentheses)

These results are likewise pictorially indicated in Figures 2 to 7 .

1) South West Region of Cameroon women's political participation and membership of political parties across their educational levels.

Figure 2 gives a summary of the results.

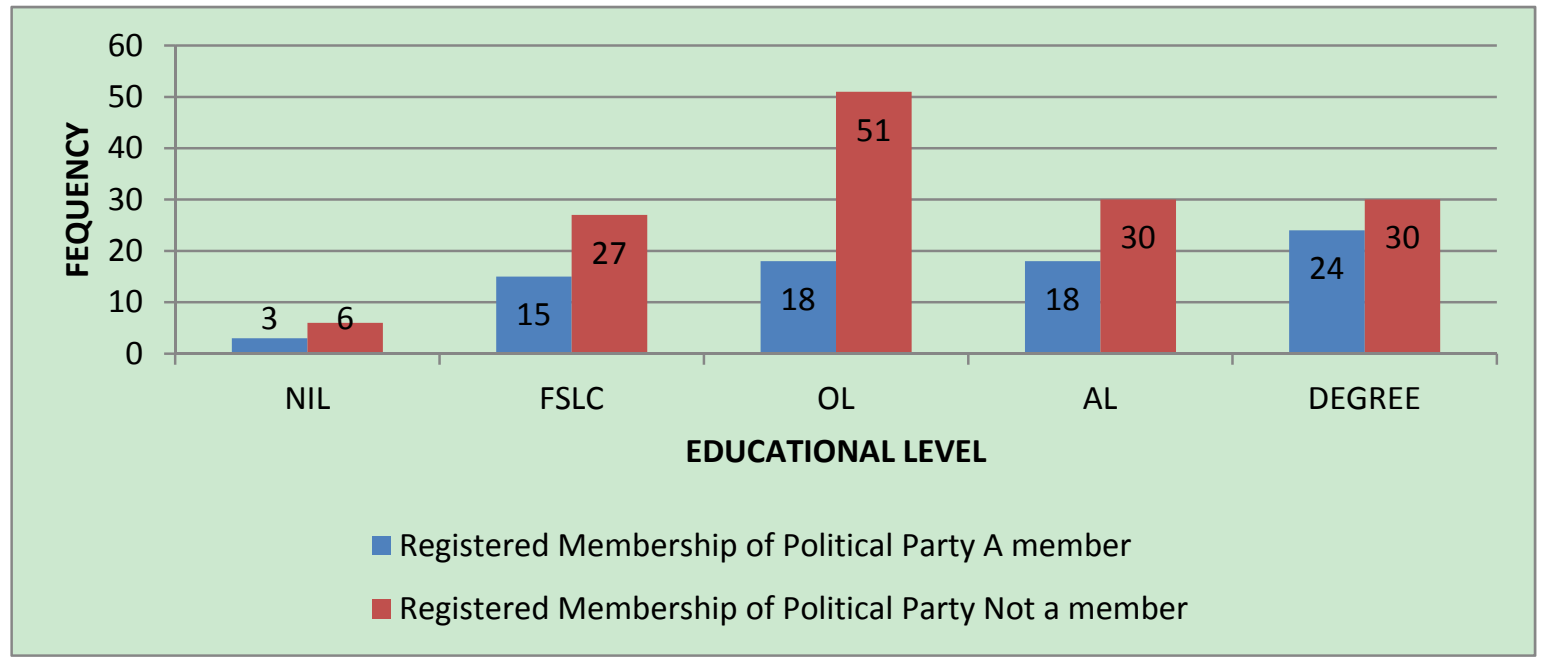

Figure 2. Chart indicating the distributions of women of the south west region of Cameroon by membership of political party across educational level 
From the Table 3 and Figure 2, 78 (35.1\%) women agreed that they are registered members of various political parties with 15 who are holders of FSLC, 18 are holders of GCE O Level, and 24 had at least university graduates. The $\mathrm{X}^{2}$ yielded a p-value of 0.32 indicating no significant statistical relationship between women's membership of political parties and their educational level at the 0.05 level of significance. It could thus be asserted that although no statistical difference existed in political participation based on education, it could be observed that the proportion of participation tends to increase with educational level.

2) South West Region of Cameroon women's political participation and voting in elections across their educational Levels:

The results are pictorially presented in Figure 3 .

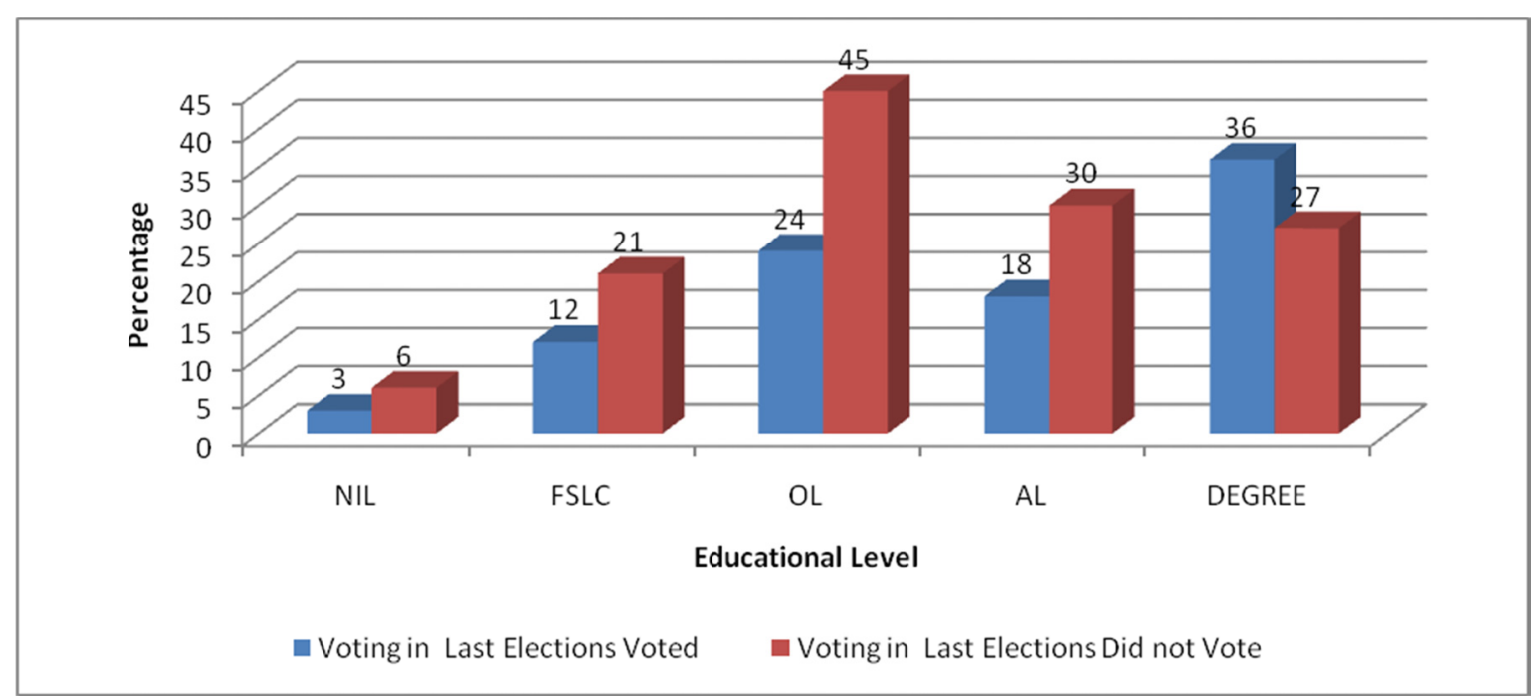

Figure 3. Chart indicating the distributions of women of the south west region of Cameroon and voting in elections by educational level

From the Figure 3 and Table 3, it $\mathrm{t}$ could be observed that women who voted during the last elections in the region increases as their educational level increases and that although the proportion of those that did not vote was consistently higher than those that voted among women in each of the educational levels, the reverse however was observed for those with at least a university degree. The $\mathrm{X}^{2}$ test yielded a p-value of 0.04 indicating that a significant statistical relationship exists between voting in elections and women's educational level at 0.05 level of significance. It could thus be inferred that as regards voting in elections, women's level of education tends to be a high contributing factor. This is especially more so as regards women with at least a degree as this group of women tend to have higher members that participated in politics through voting than those that did not participate in politics through voting.

3) South West region of Cameroon Women's political participation based on their occupation of political post across their educational levels:

Figure 4 gives a pictorial summary of the results with regards to occupation of political posts $i$ as an index of political participation. 


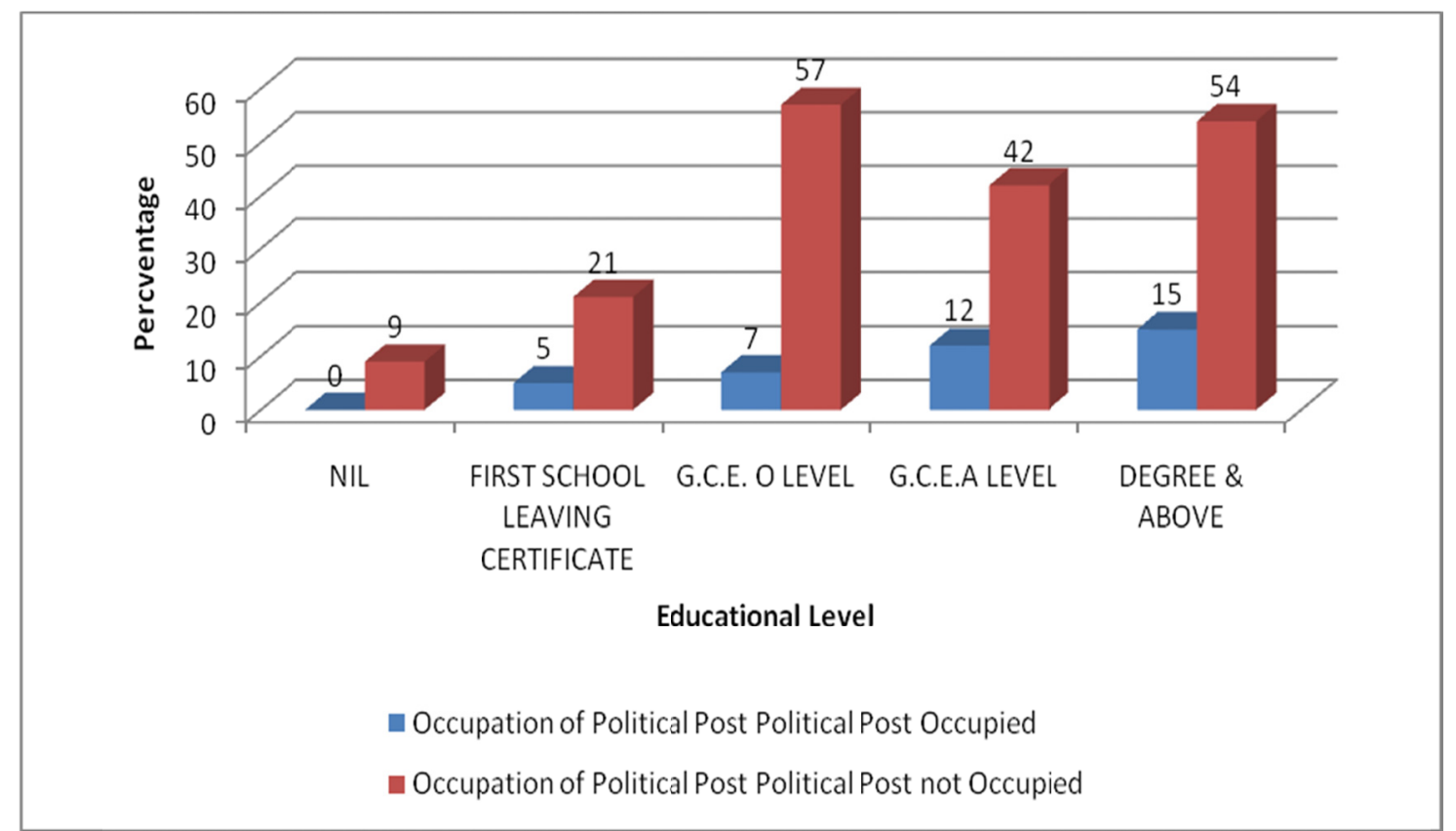

Figure 4. Chart indicating the distributions of women of the south west Cameroon and occupation of political post by educational level

Table 3 revealed that 39 (17.6\%) women occupied political post in the region across the various levels of educational attainment and that as their educational level increased, the proportion of women who occupied political post also increased. It thus seems that women's political participation with regards to occupation of political post tend to linearly vary with women's level of formal education. The $\mathrm{X}^{2}$ yielded a p-value of 0.27 which however indicates no significant statistical relationship between the occupation of political posts and women's educational level at 0.05 level of significance.

4) South West region of Cameroon women's political participation based on their means of occupation of political post across their educational levels:

With regards to means of occupation of political post, the results are pictorially presented in Figure 5.

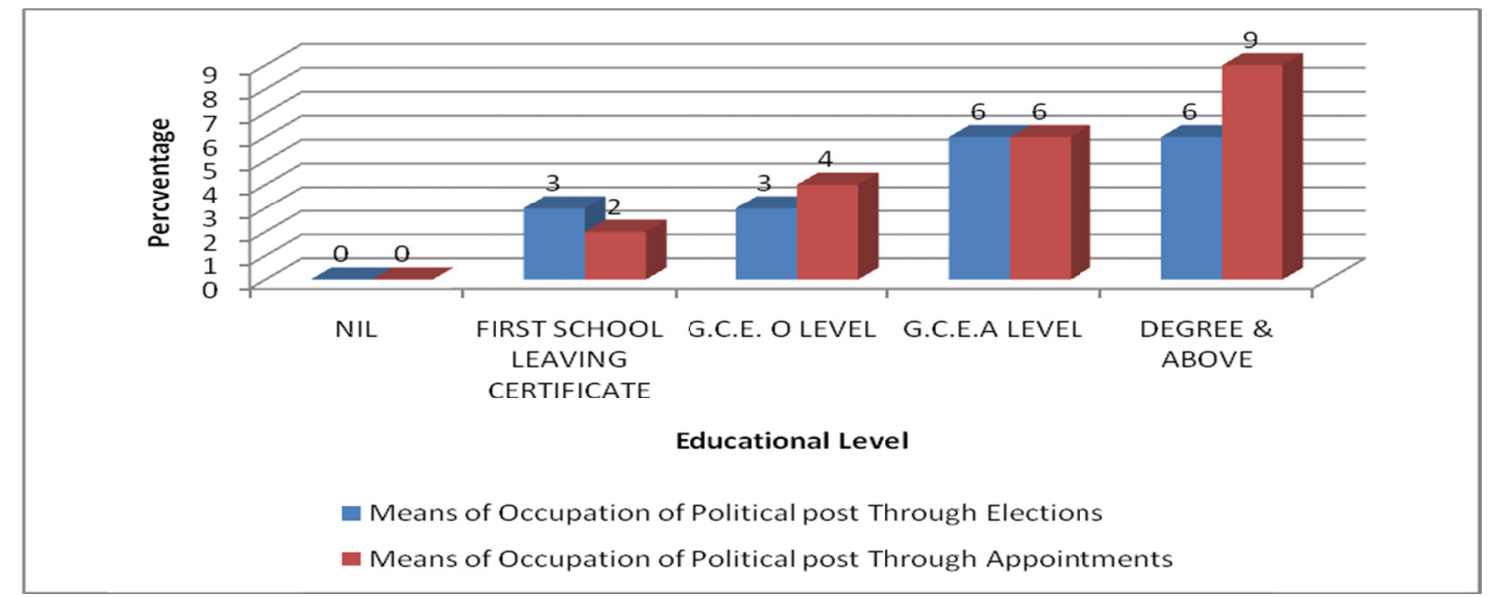

Figure 5. Chart indicating the distributions of females of south west region of Cameroon means of occupation of political post by educational level

Table 3 and Figure 5 show that $18(8.1 \%)$ women occupied political posts through elections while 21(9.5\%) got political posts by appointments. These results further showed that women with higher educational levels occupied political posts via both elections and appointments. 
5) South West Region of Cameroon women's political participation based on their Level of Occupation of Political Post across their eeducational Level:

\section{Level of Occupation of Political Post}

With regards to the level of occupation of political post, the results are pictorially presented in Figure 6.

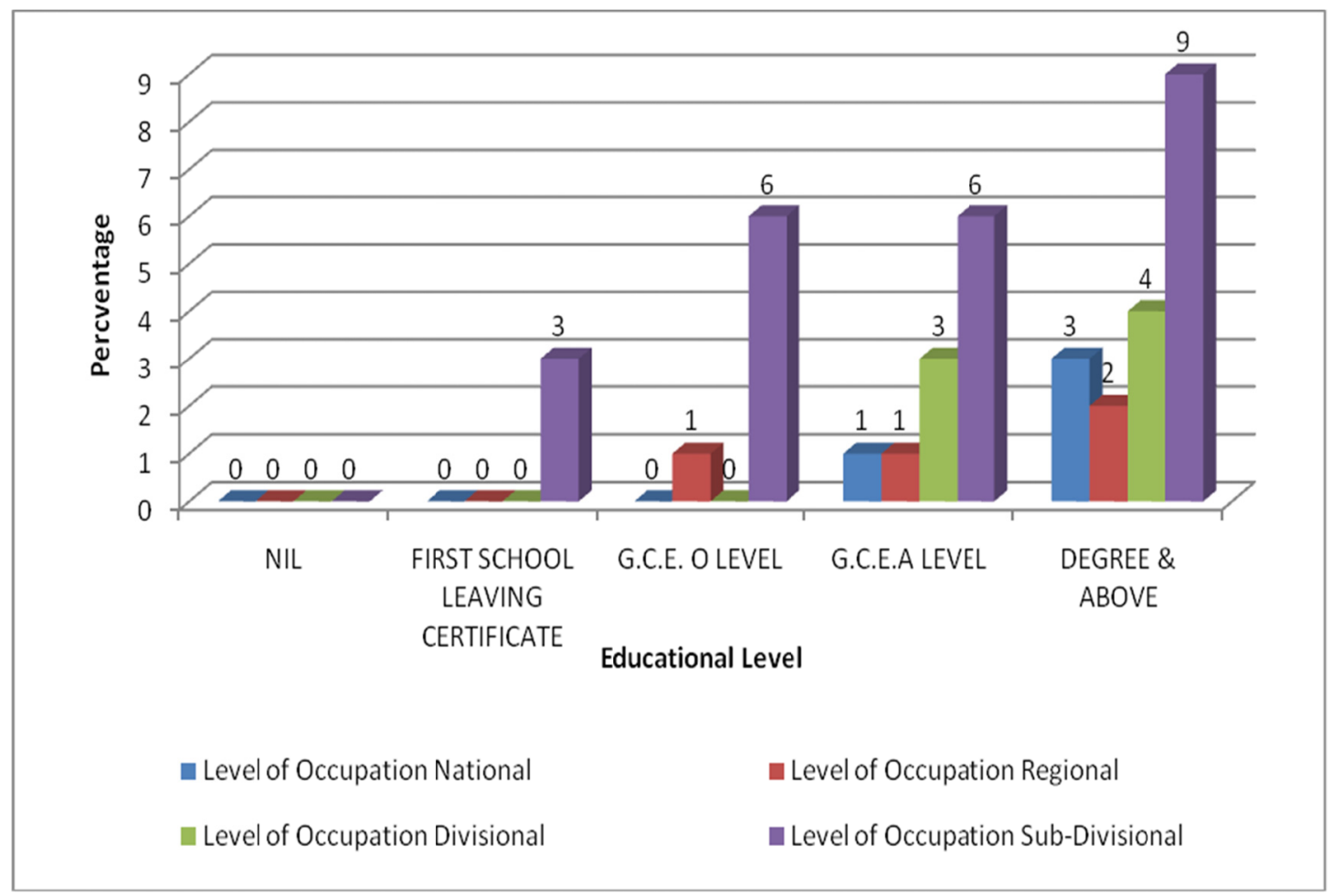

Figure 6. Chart indicating the distributions of females of south west region of Cameroon level of education by educational level

The Table 3 and figure 6 portrays that across the different educational levels, 4 women (1.8\%) women occupied political post at the national level, $4(1.8 \%)$ at the regional level, $7(3.2 \%)$ at the divisional level and $24(10.8 \%)$ at the sub divisional level. A further look at the data showed that as educational level increased, women's occupation of political post across various levels of government increased.

\section{Discussions}

The study examined the impact of women's educational level and political participation. The results have portrayed that the levels of formal education of women in South west region of Cameroon affect their levels of political participation. The results of this study are supported by the works of Dee (2004: 1697-1720) who maintained that educational attainment itself has a large and significant impact on levels of political participation. In the same vein, Milligan, Moretti, and Oreopoulos, (2003: 1667-95) argued that education connotes sophistication and thus have influence on the nature or quality of participation just as well as in its outcomes. While Sondheimer and Green (2010: 174-189) informed that educational attainment exogenously induced changes in human beings and this ensures high level of political participation in terms of higher voters' turnout, membership in political parties, attending political rallies and campaigns and occupation of political posts among others. Similarly, Milbrath and Goel (1977) asserted that educational attainment and higher participation are positively correlated as they argued that greater awareness of government activities, more advanced opinions, and greater confidence in one's ability to influence government result from higher education.

\section{Conclusions and Recommendations}

From the findings of this study, it is possible to conclude that the women of the South West region of Cameroon are fairly well exposed to formal education. The study further showed that the higher the educational level of women, the higher their level of political participation especially in areas of voting in elections and occupation of political post either through elections or appointments across all levels of government. 
The findings of this study indicate high level of association between women's level of formal education and participation in political, the study thus recommends the encouragement of formal adult education for women in South West region of Cameroon to acquire at least a university degree. Several means to attain this could be explored which may include increasing access to higher education for women, providing assistance in forms of loans and grants to women to acquire higher education.

\section{References}

Abua, D., \& Charles, F. (2004). Gender and Poverty Alleviation in Cameroon. In Endeley Joyce et al. (Eds.), New Gender Studies. UK Lighting source Ltd.

Burns, N., Schlozman, K. L., \& Verba, S. (1997). The public consequences of private inequality: Family life and citizen participation. American Political Science Review, 91. http://dx.doi.org/10.2307/2952362

Burns, Nancy, Schlozman, \& Verba. (2001). The private root of public action: Gender Equality and Political Participation. Cambridge, MA: Harvard University press.

Dee, T. S. (2004). Are there civic returns to education? Journal of Public Economics. http://dx.doi.org/10.1016/j.jpubeco.2003.11.002

Huntington, S. P., \& Nelson, J. M. (1976). No Easy Choice: Political Participation in Developing Countries. Cambridge, Mass.: Harvard University Press. http://dx.doi.org/10.4159/harvard.9780674863842

Julie, D. (2005). Introduction to Sexual Health and Reproductive rights: Refocusing priorities. Development, 48(4). Society for International Development. Palgrave- Macmillan.

Milbrath, L., \& Goel, M. L. (1977). Political Participation. Chicago: Rand McNally

Milligan, K., Moretti, E., \& Oreopoulos, P. (2003). Does education improve citizenship? Evidence from the US and the UK. NBER working paper 9584.

Ministry of Empowerment and Family. (2010). Cameroon: 53th Session of the commission on the Status of women; 15 year review of the implementation of the Beijing declaration and Platform for Action (1995) and the outcomes of the $23^{\text {rd }}$ special session of the General Assembly (2000) Statement by the Minister of Women Affair and the Family of the Republic of Cameroon Accessed 2013 online.

Oxford University Press Online Resource Centre. (2014). Definitions of political participation. Retrieved from http://global.oup.com/uk/orc/politics/comparative/caramani2e/01student/additional/ch18/01/

Phillips, A. (1991). Engendering Democracy. Polity Press, Cambridge.

Rosenstone, S. J., \& Hansen, J. M. (1993). Mobilization, participation, and democracy in America. New York: Macmillan Publishing Company.

Sondheimer, R. M., \& Green, D. P. (2010). Using experiments to estimate the effects of education on Voters turnout. American Journal of Political Science, 54(1). http://dx.doi.org/10.1111/j.1540-5907.2009.00425.x

UN women' watch. (2014). Political participation. Retrieved from http://www.un.org/womenwatch/osagi/ wps/publication/Chapter3.htm

UNDP. (2005). Human Development Report on Turkey. New York: United Nations.

Verba, S., Schlozman, K. L., \& Brady, H. (1995). Voice and Equality: Civic Voluntarism in American Politics. Cambridge, Mass.: Cambridge University Press.

\section{Copyrights}

Copyright for this article is retained by the author(s), with first publication rights granted to the journal.

This is an open-access article distributed under the terms and conditions of the Creative Commons Attribution license (http://creativecommons.org/licenses/by/3.0/). 